\title{
Stowe's sunny memories of Highland slavery
}

\author{
Judie Newman
}

[They], counting the natives as their slaves and their prey, disposed without scruple of them and all that they had, just as it suited their own interest or convenience, reckless of the wrongs and misery they inflicted on these simple, unresisting people ... removed from their comfortable houses and farms in the interior. ${ }^{1}$

An almost sublime instance of the benevolent employment of superior wealth and power in shortening the struggles of advancing civilisation. ${ }^{2}$

Two descriptions of the same system: one from Harriet Beecher Stowe, staunch abolitionist and unwavering champion of the oppressed African American, the other from one of her most relentless opponents. But which is which? In this case the system is not slavery but the Highland Clearances, and it is the second quotation which comes from Stowe, whereas the first is taken from Donald MacLeod's furious riposte to her. MacLeod's account of the forced eviction of the tenants of the Duchess of Sutherland, their homes burnt over their heads, their surviving families removed to the barren coastal lands, the 'fortunate' ones becoming unwilling emigrants to Canada, spares no punches in its descriptions, which draw upon eye-witness acounts, and his own bitter experience during the clearance of the entire Naver valley. It stands in strong contrast to Stowe's glowing depiction of the happy condition of the Sutherland tenantry in their model cottages under the benevolent control of the Duchess. The latter had sponsored an address against slavery, 'An Affectionate and Christian Address of Many Thousands of Women of Great Britain and Ireland to Their Sisters the Women of the United States of America' signed by some 576,000 British women in 1852, and presented to Stowe at the Duchess's palatial residence, Stafford House, on 7 May 1853. The Duchess had entertained Stowe lavishly on her visit to 
Britain, presenting her with a gold bangle in the shape of a slave's shackle. But Stowe had relied for her account of the Sutherland estates (Letter XVII of Sunny Memories) on secondhand information, derived from James Loch, the Duchess's agent. As a result she offered ammunition on a plate to pro-slavery activists. How could Uncle Tom's Cabin be believed if its author were so careless with her evidence? As MacLeod put it,

If you took your information and evidence upon which you founded your Uncle Tom's Cabin from such discreditable sources ... who can believe the one-tenth of your novel? I cannot. (Gloomy, p. 122)

The pro-slavery strategy of comparing the lot of the European labourer unfavourably with that of the slave was readily invoked, with exhortations to the Duchess to attend to philanthropy at home before venturing to intervene in American affairs, as Horace Perry Jones has observed. ${ }^{3}$ As late as 1963, John Prebble ${ }^{4}$ described Stowe as ignorant of the facts of both the Clearances and slavery, and dismissed Uncle Tom's Cabin as wholly inaccurate.

Why did Stowe make this mistake? And why did she repeat it? Sunny Memories was written after Stowe had been made aware of the charges against the Sutherlands. Indeed, in her preface she is squarely on the defensive, defying her critics:

If the criticism is made that everything is given couleur de rose, the answer is Why not? They are the impressions, as they arose, of a most agreeable visit. How could they be otherwise? (Sunny, p. ix)

Contradictorily, at the same time she states that she is publishing her travel letters only to correct 'the persevering and deliberate attempts, in certain quarters, to misrepresent the circumstances which are here given'. (Sunny, p. ix). Letter XVII is entirely devoted to a defence of the Duchess, with Stowe extolling the 'improvements' in the estate (on which she had yet to set foot), detailing the mileage of new roads, the number of banks, schools, post offices, and even describing the complete conversion of the inhabitants to temperance. ('There is not, I believe, an illegal still in the county' (Sunny, p. 221), she declares, a statement which convicts her on the spot of extreme credulity, to anyone who knows Sutherland, then or now.) MacLeod took her to pieces in Gloomy Memories, contesting and disproving every single point. Despite the potential libel on the Sutherlands, facts are, as MacLeod puts it, 'stubborn chiels' (Gloomy, p. 120); he was never challenged or refuted, and his account was fully substantiated as a result of the Royal Commission of 1883 , assisted by the discovery of an eye-witness 
diary account by a Caithness churchman, Donald Sage. On her second European tour Stowe did visit the Sutherland estate, and comments in a letter to her husband on 15 September 1856, from Dunrobin Castle, the Duchess's seat, that 'I am showered with letters, private and printed' imploring her to see for herself the evidence of abuse and misery. ${ }^{5}$ In response she extolled the virtues of the Sutherlands, describing the Duke as unselfishly spending the entire income of the estate on its improvements, and the estate itself as akin to a garden. In short 'Everything here is like a fairy story'. (Life and Letters, p. 218). Indeed, the Duke offered to have the castle (architecturally rather akin to Disney's trademark Ruritanian fantasy) illuminated in celebration if Fremont won the American election (Life and Letters, p. 222). Even thirteen years later, when the evidence was surely incontestible, Stowe repeated the material, in her memorial of the Duchess, once more exonerating the Sutherlands.

What reason could Stowe have for whitewashing a Highland landlord? Various arguments have been advanced. Later commentators have tended to follow Stowe's own account. Forrest Wilson, for example, simply dismisses all charges, repeating Stowe's own point that there was confusion between the first Duchess of Sutherland (died 1839) who was responsible for the Strathnaver Clearances, and Stowe's own friend, who became Duchess of Sutherland only on her marriage in $1823 .{ }^{6}$ Whether or not there were abuses, Stowe argued, it was well before her time. MacLeod, of course, pointed out that there had been no change in the landlords' policy throughout the period. Clearances continued, including, in 1853 when Stowe was in Britain, a particularly brutal clearance in Knoydart. Frank Klingberg and Howard Temperley ascribe the success of Stowe's tour to her achievement in preserving the unity of a severely factionalised movement - which any sign of criticism of the Sutherlands would have threatened. ${ }^{7}$ Joan Hedrick, while not pronouncing one way or the other on the question of the Clearances, similarly understands Stowe's defence of the Duchess as part and parcel of her conciliatory position, carefully maintaining her own neutrality between different abolitionist factions. ${ }^{8}$ In addition, Chris Mulvey notes that Stowe's ideal model of society as an extended family made her vulnerable to the attractions of the aristocracy, especially where the nobleman could also be seen as a force for progress and commercial improvement. ${ }^{9}$ Stowe's interest in improvements readily disposed her towards the clearances, as a 'progressive' modern movement (she spent some time visiting model lodging houses and schools, while in Britain).

George Shepperson (in much the most extensive discussion of the 
topic) apparently makes one point in Stowe's favour in underlining the fact that Stowe had not actually visited Sutherland when she penned Sunny Memories, implicitly correcting the error made by Prebble, who dates Sunny Memories after the second visit (i.e. when Stowe should have known better). Shepperson argues that she had access only to secondhand information, in other words that it may have been a relatively innocent mistake, at least initially. In addition, he notes the importance of Stowe's visit in stimulating the 'Free Cotton' argument, and in lending respectability to the abolitionist cause. While not letting Stowe off the hook completely, Shepperson also notes the problems facing anyone in gaining access to the truth. The evidence of illiterate Gaelic speakers on the north coast of Scotland was unlikely to outweigh the 'facts' as presented by James Loch and the Sutherland estate to a London audience. ${ }^{10}$ Geography was also a factor. Even when in Sutherland, Stowe was on the east coast, and in the close vicinity of Dunrobin, the Duchess's seat. Without going as far as MacLeod who accused the Duchess of staging a 'Prince Potemkin'-style display of temporarily done-up cottages and happy peasants expressly for Stowe's benefit (Gloomy, p. 140), there is all the difference in the world between the circumstances of farmers and estate workers in the shadow of the castle, and the inhabitants of the far north-west (most of which is reached, even now, at the expense of some time and difficulty by single-track road). In addition, as Shepperson also notes, there may have been a personal factor. Stowe's son, Henry, who much enjoyed his visit to Dunrobin, died in an accident in 1857 shortly after their return. In a letter to the Duchess on 3 August 1857 communicating the news of Henry's death, Stowe writes that 'Dunrobin will always be dearer to me now'. (Life and Letters, p. 240). The Duchess lost her own son in the Crimea and the two women were clearly brought closer together by mutual grief.

Be that as it may, it is none the less arguable that Stowe did know what she was doing and did it expressly. My argument has two main points: first, despite its date (and pace Shepperson), Sunny Memories was designed from the outset to combat MacLeod, who had published his accusations originally in a series of letters to the Edinburgh Weekly Chronicle in 1840-41, republishing them in expanded form in 1841 as History of the Destitution in Sutherlandshire. Stowe did not act in ignorance of the charges, even on her first visit. Second, Stowe's strategy was not focused upon the contrast between the slave and the wage labourer, but upon the strikingly close parallels between the slave and the Highlander. It was relatively easy to highlight the differences between a 
plantation slave and an urban labourer in a European city. It was not so easy to contest the parallels between the slave and the inhabitant of a semi-feudal rural estate under aristocratic 'guardianship'.

To take up the first point: Sunny Memories (particularly in the British letters) is not so much a travel book as a work of polemic. Despite her professed enthusiasm for Scottish ballads, Burns and Scott, Stowe seeds her text with strategic images of a modern, 'improved' Scotland, to pave the way for her defence of the Sutherlands in Letter XVII. Approaching Glasgow by night she is alarmed that the country appears to be on fire like a raid from the Highlands' (Sunny, p. 37) and relieved when the fires turn out to be iron foundries. These may be 'less picturesque than the old beacons' (Sunny, p. 37), but their hammers are decidedly better than the clash of claymores. In short the Highlands represent a savage past. Walter Scott may be wonderful but he 'belonged to a past, and not the coming age' (Sunny, p. 51). He is only picturesque to American eyes because safely removed by time. She continues:

One might naturally get a very different idea of a feudal castle by starving to death in the dungeon of it, than by writing sonnets on it at a picturesque distance. (Sunny, p. 51)

As for popular Scottish champions, she comments on Jane Porter's The Highland Chiefs that:

Many a young woman who has cried herself sick over Wallace in the novel, would have been in perfect horror if she could have seen the real man. (Sunny, p. 52)

Unsurprisingly, the clan system comes in for no wistful nostalgia. Commenting on the speaking skills of the Duke of Argyll, Stowe declares that 'it is much better to deliver a lyceum lecture than to lead a clan in battle' (Sunny, p. 53). MacLeod had made much of the loss to the British army occasioned by the clearances. Stowe had defended them as the inevitable civilised turning of swords into ploughshares. At the Duchess's London residence she admires two retainers in full Highland costume, but when two bagpipers perform her tune changes:

Their dress reminds me in its effect, of that of our American Indians, and their playing is wild and barbaric. (Sunny, p. 309)

Having written off the Highlanders as barbaric remnants of a past age (rather like Vanishing Americans) she sketches the future in an account of a visit to cottages at Dryburgh. The suggestion of a parallel between slaves and labourers is briskly rebutted by her host ('we are no slaves' 
Sunny, p. 109) who goes on to argue that the affairs of the working classes have greatly improved since 'this emigration to America' (Sunny, 109). The cottage is eulogised in terms of its neatness, evidence of industry, proximity to schools, and excellent tea table, together with the Christian grace said over it. Slyly Stowe points out that her host is a mason with a son in America. MacLeod was, like his father, also a mason, now exiled in North America. Clearly masons had nothing at all to complain about! It is a small touch which betrays Stowe's polemical intention.

Why was Stowe so exercised on this matter? The answer has a special resonance for contemporary historians. Following the 'historians' controversy' in Germany in 1986 over the use of history for political purposes, scholars have become familiar with the dangers of making historical arguments that tend either to 'relativise' or to 'normalise' the Nazi state's killings of Jews. Discussing Ronald Reagan's respectful tribute at the graves of SS soldiers at Bitburg in 1985, Geoffrey Hartman warned of

a more subtle revisionism ... all around us that mitigates the horrors of the camps, not by denying it but by using equalizing comparisons. ${ }^{11}$

In this way Vietnam becomes a Holocaust - or (a more vexed issue following Elkins) slavery a psychological equivalent of the camps. It is a problem that besets any comparative study, offering a fatal temptation to writers to indulge the rhetoric of blame with rival calculators totting up the mortality rates. Stowe was there before us, and saw the pitfalls at her feet. As my opening quotations suggest, the parallels between African slaves and Highlanders were all too suggestive, and were immediately noted as such. When one ship, the James, reached Canada from Scotland in 1826 the Governor General commented that 'there are not many instances of slave-traders from Africa to America exhibiting so disgusting a picture'. (Gloomy, p. 206). When the Sarah and the Dove sailed from Scotland to Pictou in Nova Scotia in 1801, 700 Sutherlanders were on board: Prebble notes that if they had been slave ships they would have been allowed to carry only 489 passengers (Highland Clearances). Without explicitly invoking the Middle Passage, MacLeod made much of the horrors of the voyage: 'six weeks' dreary passage, rolling upon the mountainous billows of the Atlantic, ill-fed, ill-clad, among sickness, disease and excrements' (Gloomy, p. 155). Physical violence and restraint were an experience common to both slaves and Scots. In August 1851, in the clearance of Barra and South Uist (just before Stowe's first visit) those who fled the emigrant ship were pursued, beaten, dragged on board and handcuffed. Macleod comments: 
the duplicity and art which was used by them in order to entrap the unwary natives is worthy of the craft and cunning of an old slave trader ... One stout Highlander ... resisted with such pith that they had to handcuff him before he could be mastered. One morning, during the transporting season, we were suddenly awakened by the screams of a young female who had been recaptured in an adjoining house after her first apprehension. We all rushed to the door and saw the broken-hearted creature with disshevelled hair and swollen face, dragged away by two constables and a ground officer. Were you to see the racing and chasing of policemen, constables and ground officers, pursuing the outlawed natives you would think, only for their colour, that you had been by some miracle transported to the banks of the Gambia on the slave coast of Africa. (Gloomy, p. 164)

Those who did get away (hiding in the hills) never saw their families again, of course. Macleod again foregrounds the parallel with slavery:

The expulsion ... the manhunt ... the violent separation of families, the parents torn from the child, the mother from her daughter ... For cruelty less savage the dealers of the South have been held up to the execration of the world. (Gloomy, p. 166)

The 'Affectionate Address' had emphasised the fact that the slave was denied the sanctity of marriage and education in the truths of the Gospel, and had appealed to sisters, wives and mothers on those grounds. The Address was a very carefully couched, middle-of-the-road, ostensibly apolitical document. It is a fair assumption that these two issues were the safest and most unchallengeable grounds on which the abolitionists could found their case - the nineteenth-century equivalent of 'Mom and apple pie'. Under the new 'improved' Sutherland regime, the inhabitants suffered from the same prohibitions. Nine out of ten of them were members of the Free Church. They were not permitted to build churches or manses for their pastors. The punishments for assisting or sheltering a persona non grata were also severe: anyone giving overnight shelter to a Protesting minister was evicted. As a result, Free Church Ministers were at least as exposed to the elements as fugitive slaves. One minister had to make a round trip of 88 miles without any shelter at all in order to preach - no light thing in the north of Scotland. ${ }^{12}$ Since the Sutherlands were not themselves Presbyterian, MacLeod drew the astute conclusion that this had little to do with religion and much to do with suppression of the truth.

The Free Church threatens to translate [their] wrongs into English -the Gaelic language removes a district more effectually from the influence of 
English public opinion than an ocean of 3000 miles - the British public know better what is doing in New York than what is doing in Lewis or Skye.

(Gloomy, pp. 198-200)

Church land was also often the only place from which a Highlander could not be violently evicted. Angus Campbell, evicted at Rogart, took up residence in a temporary booth which he erected over his father's grave in the churchyard. Unwilling to use force, the minister and factors conceded the case. Once Campbell was back home, they simply evicted him again, taking care to bar all entry to the churchyard first (Gloomy, p. 98). In 1828, MacLeod found that the Strathnaver church had actually been demolished and its timbers used to build an inn at Altnaharra. Just as in the American South, the established church supported the landowners, either physically (the Reverend Beatson is described as pursuing escaping emigrants 'like a gamekeeper': Gloomy, p. 64) or by inculcating habits of Christian submission, arguing that their sufferings were all the result of their sins. In the clearance at Culrain in 1820, where the militia fled before a large crowd of women, the Reverend Macbean spent forty-eight hours describing the torments and fires of Hell, until he broke the people's will. Since the churchmen were often the only literate people in the area, and since the Sutherland estate received tenants' petitions only if written in English and supported by a character reference from the minister, the Highlanders had almost as little protection from the law as the slave. In her memoir of the Duchess, Stowe somewhat ingenuously ascribes the practice of getting all cases in writing to the Duke's deafness (Sunny, p. 247).

The new tenants of the cleared lands were appointed JPs. If a case did come to court it had to be 'interpreted' from Gaelic to a jury of English speakers; when one sheriff (Robert McKid) visited the north-west and took evidence which established the truth, he was immediately dismissed from office. Ostensibly to discourage overpopulation, the Sutherlands also issued edicts forbidding marriage on their land. If a crofter's son married, he had to leave the croft - effectively marriage by permission. Donald Ross notes that after the recruiting officers had failed to raise one single recruit in Sutherland in the aftermath of the clearances, the young men of the county forwarded a statement to the newspapers explaining themselves as follows:

We have no country to fight for, as our glens and straths are laid desolate, and we have no wives nor children to defend, as we are forbidden to have them. We are not allowed to marry without the consent of the factor. ${ }^{13}$ 
MacLeod states that this led to 'a great amount of prostitution' and an increase in 'illegitimate connections and issues' (Gloomy, p. 137). Sutherland may not offer a precise parallel with the whorehouses of New Orleans, but any threat to the sanctity of marriage was highly damaging evidence, in abolitionist and evangelical circles.

Just as Stowe (and the 'Affectionate Address') had appealed to motherhood as the transcendent value, so commentators on the clearances drew attention to the plight of the Highland Mother - flung out in the heather with sick children, giving birth in public in the midst of a clearance as her home flamed, dragged from a burning house with her clothes on fire - all well-attested incidents. 'Mothers in Christian Britain, look, I say, at these Highland mothers who conceived and gave birth, and who are equally as fond of their offspring as you can be', declaimed MacLeod (Gloomy, p. 155). The Morning Chronicle (7 October 1856) addressed Stowe in her own sentimental rhetoric:

You are a mother, Mrs Stowe ... Will you therefore kindly ask the wife of Angus Sutherland how she felt when, less than three months ago, she and her little ones - then ill of measles - were thrown out of their humble home? Will you get the wife of Angus McKay to narrate to you how, only last year, a few days after suffering the pangs and going through the perils of maternity, she with her new-born white babe and other little ones, was mercilessly carried out in a sheet, and left to bivouac on a bare hill without home or shelter[?]

In short, the parallels in forced transportation, physical abuse, denial of marriage, denial of the Christian religion, conniving clergymen, lack of legal protection, enforced immorality, and docility under oppression were compelling. Stowe was committed to the argument (expressed, ironically, by Augustine St Clair in Uncle Tom's Cabin ${ }^{14}$ ) that 'the thing itself is the essence of all abuse' - that slavery was morally wrong in itself, regardless of parallels with any other system. To admit one parallel case would have been to set in motion a process of 'equalizing comparisons', which would have played straight into the hands of the other side.

The proof perhaps is evident in the rhetoric of Stowe's opponents. In making his parallels between Highlanders and slaves MacLeod ran the risk of perpetuating racism, and broadening its sphere by unleashing a third term - the imperialised - uncritically employed. One of MacLeod's less palatable suggestions was that, were the Duke to offer the slaves the place of the Highlanders, they would beg to be returned to slavery:

But if it was possible or practicable to try the experiment, that is, to bring 190000 of the American slaves to Sutherlandshire, and give them all the 
indulgence, all the privileges, and comforts the aborigines of that county do enjoy, I would risk all that is sacred and dear to me, that they would rend the heavens, praying to be restored to their old American slave owners. (Gloomy, p. 104)

Contrasting the slaves' lot with the Highlanders' MacLeod portrayed the former as less unhappy in their slavery, on the grounds that they had never known what it was to be free, unlike the Highlanders who had only recently lost their former rights.

The child who has been born blind is not so helpless, nor so much to be pitied when he comes to manhood, as the poor fellow who has been deprived of his sight after arriving at manhood; the former never knew what light or the use of it was, and will not pine and lament over the loss of it. (Gloomy, p. 104)

Fired as he was by the wrongs of the Highlanders, it is difficult to make any allowances for MacLeod's argument here which manages to equate racist oppression with biological essentialism, physical handicap and a quite unconscious equation of African slavery with the forces of darkness. Even worse, MacLeod invokes Voltaire's example of the Cannibal Queen, whose response to being reproached for her cannibalism was to point out that, whereas Voltaire's people killed men and left them to rot, her people at least benefitted from consuming them. Similarly, he argued, the Southerners could tell the abolitionists that at least when they bought slaves 'we feed, clothe and house them' (Gloomy, p. 33) as opposed to the British who first pauperise and then abandon their 'white slaves'. Arguments of this nature have a nasty habit of reversing themselves. As added ammunition, MacLeod invoked the example of cannibalism among the starving Irish, citing the case of a boiled baby (Gloomy, p. 33). From this, it was a short step from the comparative to the globalising, and to justifications of Empire, with the Duke characterised as Nana Sahib (Gloomy, p. 223), the Highlanders as the heroes of the Indian Mutiny (Gloomy, p. 224), and of South Africa (Gloomy, p. 150), and the unconquered Celtic race the only 'pure', unmixed blood in Britain (Gloomy, p. 104), now being massacred in North America by cruel half-breeds and savage Indians (Gloomy, p. 41). In the latter example MacLeod was unaware that the leaders of the so-called savages were the Gaelic MacGillivray brothers (as Ian Grimble notes in his introduction: Gloomy, p. 29). MacLeod was, of course, in good company in exploiting an orientalising rhetoric. In Capital Karl Marx, taking the Duchess of Sutherland as an example of the worst excesses of the Clearances, compared the 
landlords to fierce Indians and Moguls. ${ }^{15}$ In MacLeod's original article for the New York Daily Tribune (9 February 1853, p. 6) the Duchess of Sutherland was described as a 'female Mehemet Ali'. Perhaps Stowe was right to prefer stonewalling to equalising comparisons.

Or did she? The story has a twist in its tail. On 9 and 16 October 1856, as Stowe headed south after her visit to Dunrobin, readers of the Northern Ensign (a Caithness paper) were treated to a long letter of repentance. Apparently realising that she had no chance of visiting the north coast on a fact-finding tour, Stowe describes how she stole into the Duke's library in search of some hard facts, only to discover to her horror that the population of Sutherland had hardly increased in fifty years, that land values were low, that there was almost no shipping or commerce, no post offices, no banks, not a newspaper or a press or a bookshop, that in short 'the material prosperity of Mr Loch's chapter in my Sunny Memories was a myth'. Stowe promptly recanted.

The bubble has burst! Chapter seventeen of my 'Sunny Memories' is a mere delusion. Oh that with one dash of my pen I could blot it out of existence, and forever wipe away the remembrance of the connection I had with it... The facts I got from the books in the library leave me no alternative but to declare my former statements ... as baseless and unfounded, and to pronounce [the] system, not 'a sublime instance of the benevolent employment of a superior wealth and power in shortening the struggles of advancing civilization', but a barbarous and cruel application of superior power.

In a full description of the various abuses, she concludes that 'I fear I did wrong in coming forward to vindicate these horrid clearances'. She has, she argues, made a rather subtle hint at the true state of the case in Dred, but cannot afford to anger the Duchess 'whose friendship is essential to the sale of my books'. As readers will gather, the letter is a transparent (and acknowledged) forgery by the editor. Stowe maintained her public silence and made no response. The editor's suggestion of a covert hint in Dred, however, may offer readers of Stowe a shred of comfort. In that novel, the Clayton family estate is a paradigm for the benevolent trusteeship of the enlightened slave-owner, with its model cottages, lyceum, and improvements of the most progressive nature. The Utopia fails when Clayton finds a party of whites at the door, torches in hand, intent on burning the house over his head, a threat which effectively clears the whole plantation, black and white, sending them to a new life in Canada. 


\section{Notes}

I am grateful for the assistance of Jim A. Johnston, and Irene Ross of the Strathnaver Museum, Clachan, Bettyhill, Sutherland.

1 Harriet Beecher Stowe, Sunny Memories of Foreign Lands, London, Sampson, Low, 1854, p. 228. Hereafter, Sunny.

2 Donald MacLeod, Gloomy Memories in the Highlands of Scotland versus Mrs Harriet Beecher Stowe's Sunny Memories In (England) A Foreign Land: Or A Faithful Picture of the Extirpation of the Celtic Race From the Highlands of Scotland, Strathnaver Museum, Farr, Sutherland, [1856] 1996, p. 85. Hereafter, Gloomy.

3 Horace Perry Jones, 'The Southern Press Follows Harriet Beecher Stowe Abroad', McNeese Review, 27 (1980-81), 36-44.

4 John Prebble, The Highland Clearances, London, Secker and Warburg, 1963, pp. 306-15 Hereafter, Highland Clearances.

5 Annie Fields (ed.), Life and Letters of Harriet Beecher Stowe, Boston, Houghton Mifflin, 1897, pp. 218-19. Hereafter, Life and Letters.

6 Forrest Wilson, Crusader in Crinoline: The Life of Harriet Beecher Stowe, London, Hutchinson, 1942.

7 Frank J. Klingberg, 'Harriet Beecher Stowe and Social Reform in England', American Historical Review, 43 (1937-38), 542-52; Howard Temperley, British Antislavery 1833-1870, London, Longman, 1972.

8 Joan Hedrick, Harriet Beecher Stowe. A Life, Oxford, Oxford University Press, 1994.

9 Christopher Mulvey, Translatlantic Manners, Cambridge, Cambridge University Press, 1990.

10 George Shepperson, 'Harriet Beecher Stowe and Scotland, 1852-3', Scottish Historical Review, 32 (1953), 40-6.

11 Geoffrey Hartmann (ed.), Bitburg in Moral and Political Perspective, Bloomington, Indiana University Press, 1986, p. 6.

12 Alexander Mackenzie, The History of the Highland Clearances, Glasgow, P.J. O'Callaghan, [1883] 1914, p. 63. Contains excerpts from Loch, MacLeod, Miller, Sage, Stowe.

13 Donald Ross, Letters on the Depopulation of the Highlands, Glasgow, 1956, p. 4.

14 Harriet Beecher Stowe, Uncle Tom's Cabin, London, Penguin, [1851] 1981, p. 332.

15 Karl Marx, Capital, ed. Frederick Engels, London, Lawrence and Wishart, 1974, p. 682. 


\section{Bibliography}

Anonymous, 'Mrs Stowe in Sutherlandshire', Morning Chronicle, 7 October 1856. 'Mrs Stowe With a Bad Cause', Evening Star, 15 October 1856.

'Sunny Memories of Sutherlandshire', Northern Ensign, 9-16 October, 1856. 'An Affectionate and Christian Address of Many Thousands of Women of Great Britain and Ireland to Their Sisters the Women of the United States of America', in Joan D. Hedrick (ed.), The Oxford Harriet Beecher Stowe Reader, Oxford, Oxford University Press, 1999, pp. 451-2.

Beecher, Charles, Harriet Beecher Stowe in Europe. The Journal of Charles Beecher, ed. Joseph S. Why and Earl French, Hartford, Stowe-Day Foundation, 1986.

Elkins, Stanley, Slavery: A Problem in American Institutional and Intellectual Life, Chicago, University of Chicago Press, 1959.

Fields, Annie (ed.), Life and Letters of Harriet Beecher Stowe, Boston, Houghton Mifflin, 1897.

Fitzhugh, George, Cannibals All! Or, Slaves Without Masters, ed. C. Vann Woodward, Cambridge MA, Belknap Press, 1960.

Fladeland, Betty, Men and Brothers: Anglo-American Antislavery Cooperation, Urbana, University of Illinois Press, 1972.

Hartmann, Geoffrey (ed.), Bitburg in Moral and Political Perspective, Bloomington, Indiana University Press, 1986.

Hedrick, Joan, Harriet Beecher Stowe. A Life, Oxford, Oxford University Press, 1994. Jones, Horace Perry, 'The Southern Press Follows Harriet Beecher Stowe Abroad', McNeese Review, 27 (1980-81), 36-44.

Klingberg, Frank J., 'Harriet Beecher Stowe and Social Reform in England', American Historical Review, 43 (1937-38), 542-52.

Loch, James, An Account of the Improvements on the Estates of the Marquess of Stafford, London, Longman, Hurst, Rees, Orme and Brown, 1820.

Mackenzie, Alexander, The History of the Highland Clearances, Glasgow, P.J. O'Callaghan, [1883] 1914.

MacLeod, Donald, Gloomy Memories in the Highlands of Scotland versus Mrs Harriet Beecher Stowe's Sunny Memories In (England) A Foreign Land: Or A Faithful Picture of the Extirpation of the Celtic Race From the Highlands of Scotland, Strathnaver Museum, Farr, Sutherland, [1856] 1996. Expanded version of History of the Destitution in Sutherlandshire (Edinburgh, 1841).

Marx, Karl, Capital, ed. Frederick Engels, London, Lawrence and Wishart, 1974.

Miller, Hugh, Sutherland and the Sutherlanders, n.p., 1844.

Mulvey, Christopher, Translatlantic Manners, Cambridge, Cambridge University Press, 1990.

Prebble, John, The Highland Clearances, London, Secker and Warburg, 1963.

Ross, Donald, The Glengarry Evictions; Or, Scenes at Knoydart in Invernessshire, Glasgow, W.G. Blackie, 1853.

L Letters on the Depopulation of the Highlands, Glasgow, 1856. 
Sage, Donald, Memorabilia Domestica, Wick, 1889.

Shepperson, George, 'Harriet Beecher Stowe and Scotland, 1852-3', Scottish Historical Review, 32 (1953), 40-6.

Stowe, Harriet Beecher, Sunny Memories of Foreign Lands, London, Sampson, Low, 1854.

— 'Tribute to the Memory of a Noble Woman', Atlantic Monthly, 23 (February 1869), 242-50.

—Uncle Tom's Cabin, London, Penguin, [1851] 1981.

Dred: A Tale of the Great Dismal Swamp, ed. Judie Newman, Edinburgh, Edinburgh University Press, [1856] 1998.

Temperley, Howard, British Antislavery 1833-1870, London, Longman, 1972.

Wilson, Forrest, Crusader in Crinoline: The Life of Harriet Beecher Stowe, London, Hutchinson, 1942. 